\title{
CHARACTERIZATION OF PLANT-BASED PROTEIN SOURCES FOR USE IN CANINE AND FELINE NUTRITION
}

\begin{abstract}
Lauren M. Reilly ${ }^{1}$, Patrick C. von Schaumburg ${ }^{1}$, Jolene M. Hoke ${ }^{2}$, Gary M. Davenport ${ }^{2}$, Pamela L. Utterback ${ }^{1}$, Carl M. Parsons ${ }^{1}$, Maria R.C. de Godoy ${ }^{1}$
\end{abstract}

\footnotetext{
1'Department of Animal Sciences, University of Illinois, Urbana, IL 61801.

${ }^{2}$ Archer Daniels Midland Company, Decatur, IL 62526

Email: mgodoy2@illinois.edu
}

\begin{abstract}
The objective of this study was to determine the macronutrient composition and standardized amino acid digestibility of 14 novel, plant-based, protein sources. The 14 protein sources are comprised of protein concentrates (pea, potato, faba bean, yeast, and soy concentrates), pulses (garbanzo beans, navy beans, black beans, lentils, and peas), and byproducts (corn gluten meal, peanut flour, soybean meal, and soy flakes). Macronutrient compositions and a complete amino acid profile were analyzed for all 14 protein sources. Cecectomized roosters ( $n=4 /$ treatment) were utilized in a precision-fed rooster assay to measure standardized amino acid digestibility and true metabolizable energy corrected for nitrogen (TMEn). The roosters were precision-fed $30 \mathrm{~g}$ of a 1:1 ratio of an ingredient and corn mixture. Excreta was collected after 48h, freeze-dried, and analyzed for a complete amino acid profile. Due to the high amino acid digestibility and well-balanced essential amino acid profiles, these plant-based proteins have the potential to become viable protein sources in canine and feline diets.
\end{abstract}

Keywords: plant proteins, cecectomized roosters, digestibility

Introduction: Plant-based proteins are under-utilized as protein sources in the pet food industry. However, the rapidly increasing human population will require a 233 million ton increase in meat products by 2050 (Boland et al., 2013). The increasing global population, along with consumer demand to see more non-traditional diets on the market, create a need for alternative protein sources. However, the use of novel protein sources is restricted due the limited research available on macronutrient composition and nutrient digestibility (Deng et al., 2016). In this study, precision-fed rooster assays were used to determine amino acid digestibility and TMEn. Precision-fed rooster assays are used as an accurate predictor of in-vivo digestibility as it eliminates the influence of hindgut microbial fermentation (Johnson et al., 1997).

Materials and Methods: All 14 protein sources were analyzed for dry matter, ash and organic matter (AOAC, 2006), crude protein (AOAC, 2006), gross energy (bomb calorimetry), acid hydrolyzed fat (AACC, 1983; Budde, 1952), and total dietary fiber (Prosky et al., 1992). Precision-fed rooster assays were conducted using cecectomized, Single Comb White Leghorn roosters. In the precision-fed rooster assay, 56 cecectomized roosters ( $n=4 /$ treatment) were fasted for $26 \mathrm{~h}$ and then precision-fed $30 \mathrm{~g}$ of a 1:1 ratio of an ingredient and corn mixture. After $48 \mathrm{~h}$, rooster excreta (uric acid + feces) was collected and freeze-dried. Complete amino acid profiles were also determined for the protein sources and rooster excreta (AOAC, 2007; method 982.30). 
Results and Discussion: The amino acid profiles were similar within the protein concentrate group and within the pulses group. There is more variation in terms of the amino acid profile for the byproducts group. However, although similar in macronutrient composition, the processing and ingredient type of the byproducts differ greatly which could account for some of this variation. The protein sources in this study showed high essential amino acid digestibility. In the protein concentrate group, there is a significant difference $(P<0.05)$ in the digestibility of lysine, methionine, and tryptophan. Potato protein had the highest TMEn content with soy protein concentrate as the lowest $(P<$ $0.05)$. In the pulses group, garbanzo beans is significantly higher $(P<0.05)$ than black bean grits in both arginine and histidine. There was no significant difference $(P>0.05)$ in the TMEn of these ingredients. The same variation seen in the amino acid profile of the byproducts can be seen in the amino acid digestibility. Soy flake and peanut flour show the lowest overall digestibility which is particularly noticeable in lysine digestibility. Peanut flour has the lowest $(P<0.05)$ lysine digestibility at $45.5 \%$. Because the peanut flour is dark roast, the lysine could have been heat damaged during processing, resulting in a lower digestibility. The peanut flour and the corn gluten meal have significantly higher $(P<0.05)$ TMEn values than the soy products, which is reflective of their higher fat content.

Conclusions: Plant-based proteins have the potential to be a viable protein source in canine and feline diets. Not only would these novel, protein sources satisfy consumer demand to see more non-traditional diets on the market, they would also increase the sustainability of the pet food industry by incorporating ingredients from multiple industries. Based on their macronutrient composition, amino acid profile, and amino acid digestibility, these proteins could potentially be used as alternative protein sources in the pet food industry.

References: Boland, M. J., Rae, A.N., Vereijken, J.M., Meuwissen, M.P.M., Fischer, A.R.H., Van Boekel, M.A.J.S., Hendriks, W.H. The future supply of animal-derived protein for human consumption. Trends in Food Science \& Technology, v.29, p.62-73, 2013.

Deng, P., Utterback, P.L., Parsons C.M., Hancock, L., Swanson K.S. Chemical composition, true nutrient digestibility, and true metabolizable energy of novel pet food protein sources using the precision-fed cecectomized rooster assay. Journal of Animal Science, v.94, n.8, p.3335-3342, 2016.

Johnson, M.L., Parsons, C.M., Fahey, G.C., Merchen, N.R., Aldrich, C.G. Effects of species raw material source, ash content, and processing temperature on amino acid digestibility of animal by-product meals by cecectomized roosters and ileally cannulated dogs. Journal of Animal Science, v.76, p.1112-1122, 1998. 